\title{
Thoracoscopic lung biopsy in a patient with pulmonary lymphan- giomyomatosis
} Tatsusuke Yoshikawa MD PhD,
Zen'ichiro Wajima MD PhD,
Akira Ogura MD PhD,
Kazuyuki Imanaga MD PhD,
Tetsuo Inoue MD PhD

Purpose: We describe the anesthetic management of a patient with pulmonary lymphangiomyomatosis (LAM) during thoracoscopic lung biopsy (TSLB).

Clinical features: LAM is a rare idiopathic disease characterised by progressive deterioration in respiratory function, occurring almost exclusively in women. In establishing the diagnosis, an open lung biopsy (OLB) has been employed in patients with relatively normal lung function. However, TSLB rather than OLB is less invasive. A 38 yr old woman developed a clinical course of cough, shortness of breath and sputum production, Chest Xray findings, ${ }^{99 m}$ T c-MAA scintigraphy and thin-sliced high resolution CT, typical of LAM, TSLB was scheduled to establish the diagnosis. General anesthesia, employing differential lung ventilation and high frequency jet ventilation combined with epidural anesthesia and continuous intravenous propofol was performed successfully. High frequency ventilation was applied to the non-dependent lung and intermittent positive pressure ventilation (IPPV) to the dependent lung with lower tidal volume and respiratory rate, allowing permissive hypercapnia. In the postoperative period, although synchronized intermittent mandatory ventilation was applied, pressure support ventilation or continuous positive airway pressure (CPAP) would have been a better selection. Postoperative sedation was performed satisfactorily using propofol.

Conclusions: We recommend general anesthesia using differential lung ventilation combined with epidural anesthesia and intravenous propofol during TSLB for LAM. Postoperative ventilation should be pressure support ventilation or CPAP to keep peak inspiratory pressure low and allow permissive hypercapnia.

Objectif : Décrire la démarche anesthésique entreprise pendant une biopsie pulmonaire pleuroscopique (BPPS) chez une patiente atteinte de lymphangiomyomatose pulmonaire (LAM).

Éléments cliniques : La LAM est une affection idiopathique rare caractérisée par une détérioration progressive de la fonction respiratoire et qui survient presque exclusivement chez les femmes. Pour poser le diagnostic, une biopsie pulmonaire ouverte (BPO) a été utilisée chez des patients dont la fonction pulmonaire était relativement normale. Cependant, la BPPS est moins effractive que la BPO. Une femme de 38 ans a connu une évolution clinique de toux, d'essoufflement et de production de crachat suivis de constatations radiographiques thoraciques typiques d'une LAM lors d'une scintigraphie 99mTc-MAA et d'une tomodensitométrie à haute résolution en couche mince. Une BPPS a été prévue pour confirmer le diagnostic. L'anesthésie réussie, comprenant une ventilation pulmonaire différentielle et une ventilation à haute fréquence combinées à une anesthésie péridurale et à l'administration intraveineuse de propofol. La ventilation à haute fréquence a été appliquée au poumon non déclive et la ventilation à pression positive intermittente (VPPI) au poumon déclive avec un volume courant et une fréquence respiratoire plus faibles, ce qui permettait une hypercapnie permissive. Après l'opération, même si une ventilation imposée intermittente synchrone a été appliquée, la ventilation spontanée avec aide inspiratoire ou avec une pression expiratoire positive (VSPEP) auraient constitué de meilleurs choix. La sédation postopératoire avec propofol s'est révélée satisfaisante.

Conclusion : Nous recommandons une anesthésie générale avec une ventilation pulmonaire différentielle combinée à une analgésie épidurale et au propofol intraveineux pendant la BPPS pour la LAM. La ventilation postopératoire devrait être une ventilation spontanée avec aide inspiratoire ou avec une pression expiratoire positive pour conserver une pression inspiratoire maximale basse et accepter une hypercapnie permissive.

From the Department of Anaesthesia, Chiba Hokusoh Hospital, Nippon Medical School, 1715 Kamagari, Inba-mura, Inba-gun, Chiba prefecture 270-1694, Japan.

Address correspondence to: Dr. Tatsusuke Yoshikawa, Phone: 81-476-99-1111; Fax: 81-476-99-1931; E-mail: FZN03121@nifty.ne.jp Accepted for publication September 11, 1999 
$\mathrm{P}$ ULMONARY lymphangiomyomatosis (LAM) is a rare idiopathic disease that mainly affects women of reproductive age. The main symptoms include cough, shortness of breath, bloodstained sputum, chylous pleural effusions and repeated spontaneous pneumothorax. The course is progressive resulting in severe impairment of lung function. The pathological findings are characterized by hyperplasia of atypical smooth muscle cells around lymphatics, bronchioli, venules and arterioles chiefly in the lung, ${ }^{1}$ causing diffuse cystic changes throughout the lung. An open lung biopsy (OLB), transbronchial lung biopsy $(\mathrm{TBLB})^{2}$ or bronchoalveolar lavage $(\mathrm{BAL})^{3}$ are reported to establish the diagnosis. We describe the anesthetic management of our patient during TSLB.

Case report

A $38 \mathrm{yr}$ old, $40 \mathrm{~kg}, 150 \mathrm{~cm}$, woman, was admitted complaining of cough, shortness of breath on mild effort and sputum that had gradually increased over the previous four years. The patient had been treated for bronchitis in another hospital. Chest Xray showed a reticulo-nodular pattern in the lower lungs bilaterally . ${ }^{99}$ nTc-MAA scintigraphy revealed round hypoperfused areas in the bilateral upper lungs. Thin-sliced high resolution CT demonstrated honeycomb-like cystic findings but there were no marked bullas in the lungs. Pulmonary function studies showed a mild restrictive defect (\%VC 78.7\%, $\mathrm{FEV}_{1.0} 71.0 \%$ ). Arterial blood gas analysis breathing room air showed : $\mathrm{pH}$, 7.42; $\mathrm{PaO}_{2} 74.1 \mathrm{mmHg} ; \mathrm{PaCO}_{2} 36.8 \mathrm{mmHg}$ and $\mathrm{SaO}_{2} 95.2 \%$. As the course and findings suggested LAM, TSLB was scheduled to establish the diagnosis.

Routine monitoring included ECG, non-invasive blood pressure and pulse oximetry and an arterial catheter was also inserted. Ten $\mathrm{ml}$ mepivacaine $1 \%$ were administered via the epidural catheter inserted at $\mathrm{T}_{7-8}$. After confirming analgesia, anesthesia was induced with $100 \mathrm{mg}$ propofol. A double-lumen endo-bronchial tube "Bronchocath ${ }^{\circledR}(35 \mathrm{Fr}$, Mallinckrodt Co. Ltd.)" was placed in the left main bronchus, facilitated by 10 $\mathrm{mg}$ vecuronium, and then differential lung ventilation (DLV) was started. Five-six millilitres mepivacaine 1\% were injected intermittently into the epidural space at intervals of $40-50 \mathrm{~min}$. Propofol was administered continuously at a rate of $4-6 \mathrm{mg} \cdot \mathrm{kg}^{-1} \cdot \mathrm{hr}^{-1}$. The lungs were ventilated with a mixture of oxygen and air. The $\mathrm{F}_{\mathrm{I}} \mathrm{O}_{2}$ was maintained at $0.3-0.5$. During DLV, the surgically manipulated lung received high frequency jet ventilation (HFJV) at $\mathrm{F}_{\mathrm{I}} \mathrm{O}_{2}$ of $1.0 ; 150$ cycles. $\mathrm{min}^{-1}$; $30 \%$ inspiratory time; 15 psi.pressure, and was sometimes inflated manually. The dependent lung received intermittent positive pressure ventilation (IPPV). To avoid barotrauma of the dependent lung, the PIP was maintained $<20 \mathrm{~cm} \mathrm{H}_{2} \mathrm{O}$ and the tidal volume $<200$ $\mathrm{ml}$. The respiratory rate was $14-16$ cycles. $\mathrm{min}^{-1}$, resulting in $\mathrm{SpO}_{2}$ from 97 to $98 \%, \mathrm{PaO}_{2}$ 110-120 mmHg and hypercapnia (maximal $\mathrm{PaCO}_{2}$ reached 65.3 $\mathrm{mmHg}$ ). Positive end-expiratory pressure was not employed. TSLB required one hour and $25 \mathrm{~min}$ to complete. The cardiovascular system was stable throughout anesthesia. The double-lumen endobronchial tube was replaced by a single-lumen endotracheal tube to perform BAL. The diagnosis was confirmed by both TSLB and BAL ${ }^{3}$. The patient remained in the ICU for three days postoperatively. Propofol was continuously administered for sedation at $2-3 \mathrm{mg} \cdot \mathrm{kg}^{-1} \cdot \mathrm{hr}^{-1}$. During sedation in the ICU, circulatory and respiratory functions were strictly monitored. A DIB ${ }^{\circledR}$ catheter (balloon type disposable continuous infusion device; DIB international Co. Ltd.) filled with $48.5 \mathrm{ml}$ bupivacaine $0.25 \%$ and $0.3 \mathrm{mg}$ buprenolphine was connected to the epidural catheter for $24 \mathrm{hr}$ for postoperative pain relief. It was refilled at the same concentration for a further $24 \mathrm{hr}$. For the initial seven hours postoperatively, the patient was ventilated by SIMV with PIP below $20 \mathrm{~cm} \mathrm{H}_{2} \mathrm{O}$. Then, propofol administration was gradually decreased and the lungs were extubated about $24 \mathrm{hr}$ postoperatively.

\section{Discussion}

For lung biopsy in LAM, TSLB should be performed as it is less invasive than other techniques. We performed general/epidural anesthesia with DLV and intravenous propofol for TSLB. The postoperative ventilatory mode should be PSV or CPAP to maintain a low PIP and allow permissive hypercapnia.

There is no previous report of TSLB with DLV for the diagnosis of LAM. The anesthetic method we chose had the following benefits: DLV provided both a better surgical field and better ventilation: epidural anesthesia provided analgesia instead of volatile anesthetics. Both epidural anesthesia and intravenous propofol were maintained throughout the perioperative period. Applying this anesthetic technique for LAM, provided the following advantages. The lower PIP and tidal volume reduced regional lung overdistension, ${ }^{4}$ and allowed permissive hypercapnia. ${ }^{5}$ The oxygen concentration was reduced to avoid further lung interstitial proliferation. We did not apply high frequency jet ventilation to the dependent lung, because HFJV during IPPV sometimes increases PIP. We did not employ PEEP because high plateau airway pressures were associated with cardiovascular depression $^{6}$ and propofol decreases left ventricular afterload and myocardial contractility. ${ }^{7}$ Volatile anesthetics, but 
not propofol, inhibit hypoxic pulmonary vasoconstriction, 8,9 and propofol inhibits airway smooth muscle contraction. ${ }^{10}$

In this case, buprenolphine was administered epidurally for postoperative pain relief. The respiratory depressing effect appeared to be negligible as the trachea could be extubated $24 \mathrm{hr}$ postoperatively. Spontaneous breathing might cause further proliferation of the smooth muscle cells around the small airways, while positive pressure ventilation might cause bullas to rupture resulting in pneumothorax. Pressure support ventilation and CPAP with a lower pressure, decrease PIP and the work of breathing to maintain spontaneous ventilation.

We conclude that general anesthesia using differential lung ventilation combined with epidural anesthesia and intravenous propofol is a suitable anesthetic technique for TSLB for lymphangiomyomatosis.

\section{References}

1 Oxorn DC, Landrigan P. Anaesthetic management for oophorectomy in pulmonary lymphangiomyomatosis. Can J Anaesth 1987; 34: 512-4.

2 Guinee DG Jr, Feuerstein I, Koss MN, Travis WD. Pulmonary lymphangiomyomatosis. Diagnosis based on results of transbronchial biopsy and immunohistochemical studies and correlation with high-resolution computed tomography findings. Arch Pathol Lab Med 1994; 118: 846-9.

3 Murata A, Takeda $\Upsilon$, Usuki J, et al. A case of pulmonary lymphangiomyomatosis induced by pregnancy. (Japanese). Japanese Journal of Thoracic Diseases 1989; 27: 1106-11.

4 Hickling KG, Walsh J, Henderson S, Jackson R. Low mortality rate in adult respiratory distress syndrome using low-volume, pressure-limited ventilation with permissive hypercapnia: a prospective study. Crit Care Med 1994; 22: 1568-78.

5 Feihl F, Perret C. Permissive hypercapnia. How permissive should we be? Am J Respir Crit Care Med 1994; 150: 1722-37.

6 Carvalho CRR, Barbas CSV, Medeiros DM, et al. Temporal hemodynamic effects of permissive hypercapnia associated with ideal PEEP in ARDS. Am J Respir Crit Care Med 1997; 156: 1458-66.

7 Hettrick DA, Pagel PS, Warltier DC. Alterations in canine left ventricular-arterial coupling and mechanical efficiency produced by propofol. Anesthesiology 1997; 86: 1088-93.

8 Marshall C, Lindgren L, Marshall BE. Effects of halothane, enflurane, and isoflurane on hypoxic pulmonary vasoconstriction in rat lungs in vitro. Anesthesiology 1984; 60: 304-8.
9 Kellow NH, Scott AD, White SA, Feneck RO. Comparison of the effects of propofol and isoflurane anaesthesia on right ventricular function and shunt fraction during thoracic surgery. Br J Anaesth 1995; 75: 578-82.

10 Yamakage M, Hirshman CA, Croxton TL. Inhibitory effects of thiopental, ketamine, and propofol on voltagedependent $\mathrm{Ca}^{2+}$ channels in porcine tracheal smooth muscle cells. Anesthesiology. 1995; 83:1274-82. 